\title{
Soybean oil added to the diet reduces Myostatin gene expression in Longissimus dorsi muscle of sheep
}

\author{
P.H. Souza ${ }^{1}$, A.C. Rego ${ }^{1}$, C. Faturi ${ }^{1}$, E.M.M. Monteiro ${ }^{2}$, E.M. Barbosa ${ }^{3}$, \\ R.C. Guimarães ${ }^{1}$, A.R. Casseb ${ }^{1}$ and E. Silva Filho ${ }^{1}$ \\ ${ }^{1}$ Instituto da Saúde e Produção Animal, Universidade Federal Rural da \\ Amazônia, Belém, PA, Brasil \\ ${ }^{2}$ Colegiado de Medicina Veterinária, Universidade da Amazônia, Belém, \\ PA, Brasil \\ ${ }^{3}$ Colegiado de Licenciatura em Educação no Campo, Universidade Federal \\ do Amapá, Mazagão, AP, Brasil \\ Corresponding author: E. Silva Filho \\ E-mail: silva.filho@ufra.edu.br \\ Genet. Mol. Res. 18 (2): gmr18149 \\ Received September 21, 2018 \\ Accepted March 06, 2019 \\ Published April 30, 2019 \\ DOI http://dx.doi.org/10.4238/gmr18149
}

\begin{abstract}
Myostatin is a protein involved in the regulation of myogenesis; animal meat quality can be influenced by its expression. Animals with low myostatin levels have increased muscle mass and are relatively stronger. We analyzed the influence of the addition of soybean, used soybean and palm oils to the diet on Myostatin gene expression in the Logissimus dorsi muscle of sheep reared in the Northeast Amazon region. A basic control diet was elaborated and used with the addition of $4 \%$ of the different oils. All animals were slaughtered at a weight of $35 \mathrm{~kg}$ and $5 \mathrm{~g}$ of Logissumus dorsi muscle was collected and RNA extracted, quantified and a RT-PCR was run. The control diet, without added oil, gave the highest Myostatin expression levels among all treatments. When unused soybean oil was added to the diet, it significantly decreased Myostatin expression and induced muscle hyperplasia, generating animals with greater musculature. The other oils did not significantly affect expresson of this gene.
\end{abstract}

Key words: Animal nutrition; $G D F-8$; Palm oil; Residual oil; Soybean oil 


\section{INTRODUCTION}

The GDF-8 (Growth Differentiation Factor -8 ) gene codes a protein produced and released by myocyte cells that affects the functioning of muscle cells, inhibiting myogenesis; this protein is also known as myostatin (MSTN) (Carnac et al., 2006). Myostatin binds to activating receptor type II to start a muscle cell signalization cascade that activates the SMAD family transcript factors (Smad2 and Smad3). These factors induce the regulation of MSTN specific genes and when applied to myoblasts provoke their differentiation into mature muscle fibers (Ge and Greenspan, 2006).

Animals with low MSTN expression or treated with substances that block its activity have considerable muscle mass and are relatively stronger (Tsuchida, 2008). Myostatin deficiency occurs naturally in sheep with some gene polymorphisms;. polymorphisms of the MSTN gene have been associated with birth weight in Iranian Makoei sheep (Farhadian et al., 2012).

In a study of MSTN gene suppression in lamb muscles, there was reduction in MSTN and increased expression of some differentiation-associated genes, such as Myf5, MyoD, and Myogenin, which were up-regulated by Smad3, thus leading to promotion of muscle cell differentiation and growth (Du et al., 2015). Lv et at. (2015) estimated MSTN expression in various muscles at different ages ( 2 days, 2 months and 6 months old), and observed significant variation in expression with age for Longissimus dorsi, soleus, gastrocnemius and extensor digitorum longus muscles.

A study analyzing the effect of increased dietary intake observed an increase in fiber diameter and cross-sectional area of some muscles (Xing et al., 2014). There also was a negative correlation between mRNA of MSTN with muscle fiber diameter and cross-sectional area; in other words, decline of MSTN mRNA apparently resulted in muscle fiber hyperplasia and hypertrophy. Myostatin expression is associated with lamb meat quality (Bagatoli et al., 2013). Another study with the Santa Inês breed and mixed breeds analyzed the MTSN expression in the Longissimus dorsi muscle and observed that high expression is associated with a low meat tenderness phenotype, and low expression apparently results in improved meat tenderness (Bagatoli et al., 2013).

We examined the influence of adding soybean oil, used soybean oil from a fryer and palm oil in diets and its association with the MSTN gene expression profile in the Longissimus dorsi muscle of sheep reared in the Amazon region.

\section{MATERIAL AND METHODS}

All procedures were conducted according to Conselho Nacional de Controle de Experimentação Animal (CONCEA) guidelines. The project proposal was approved by the Animal Use Ethics Commission (CEUA) of the Universidade Federal Rural da Amazônia (UFRA) and granted approval number 005/2013.

\section{Experiment design}

The experiment was conducted at the Metabolic Study Unit of Small Ruminants at the Universidade Federal Rural da Amazônia, Belém, Pará, Brazil (01 27' 21" S and 48 30' 16" W). We used 40 male uncastrated Santa Inês x Dorper mixed breed sheep with an average age of 80 days and an initial body weight of $18 \mathrm{~kg}$. Care included all health aspects such as control of ectoand endo-parasites using ivermectin $\left(0.5 \mathrm{~mL} / 25 \mathrm{~kg}^{\text {.liveweight }}{ }^{-1}\right)$. The subjects were 
administered vitamins A, B12, D and E. They were housed in individual $1.77 \mathrm{~m}^{3}$ cages $(1.52 \mathrm{x}$ $0.97 \times 1.20 \mathrm{~m}$ ) containing feeding and drinking recipients. The cages were protected from the rain and sunlight and had good lateral air circulation.

The basic diet was elaborated to be considered a Control diet (CD), with ground corn, soybean meal, mineral salt, and calcitic limestone. Three treatment diets were prepared and fed to subsets of the study animals: Treatment 1 (Soybean oil) is the CD plus $4 \%$ of soybean oil added; Treatment 2 (Yellow grease) is the CD plus $4 \%$ of yellow grease added (soybean oil used to fry potatoes at the university restaurant with rigorous oil source control free of animal residues), and Treatment 3 (Palm oil) is the CD plus 4\% palm oil (Elaeis guineensis). In all diets, we used a 60:40 forage : concentrate rati; the forage composed of elephant grass silage cv. Purple (Pennisetum purpureum, ) cultivated at the UFRA.

Each treatment included 10 animals and each animal was weighed every 15 days until they reached a weight of $33 \mathrm{~kg}$. They were also weighed weekly until they reached a slaughter weight of $35 \mathrm{~kg}$ after 90 days of feeding on the study diets. After slaughter, $5 \mathrm{~g}$ of Longissimus dorsi muscle was collected at the13th thoracic vertebra and kept in liquid nitrogen until laboratory analysis was performed.

\section{Laboratory proceedings}

RNA extraction was made from $3 \mathrm{mg}$ of macerated muscle tissue, mixed with Trizol reagent (Invitrogen, Carlsbad, CA, USA) and processed according to the manufacturer's recommendations. All RNAs were quantified in a NanoDrop ND-1000 spectrophotometer (Agilent, Santa Clara, CA, USA) to measure RNA concentration. The purity of the RNA was determined by A260/280 and A260/230 ratios. Samples with A260/280>2.2 were considered suitable for analysis.

\section{Real-time PCR}

Real-time PCR (RT-PCR) was performed in triplicate for MSTN and GAPDH (endogenous) genes using a Power Sybr ${ }^{\circledR}$ Green RNA-to- $\mathrm{C}_{\mathrm{T}}{ }^{\mathrm{TM}}$ one-step Kit (Applied Biosystems, Foster City, CA, USA) according to manufacturer's recommendations, with a final volume of $20 \mu \mathrm{L}$. All reactions were run using the CFX96 Touch $^{\mathrm{TM}}$ Real-Time Detection System (Bio-Rad, Hercules, CA, USA). The primer sequences for RT-PCR were designed by Primer3 online software (http://bioinfo.ut.ee/primer3-0.4.0) (Table 1).

Table 1. Primer sequences used to analyze myostatin gene expression in sheep muscle.

\begin{tabular}{|c|c|c|c|}
\hline Genes & Forward and reverse sequences & Exon & GenBank reference \\
\hline Myostatin & $\begin{array}{l}\text { TCTGAGACCTGTCAAGACTCC } \\
\text { CTCTGCCAAATACCAGTGCC }\end{array}$ & 2 & ID: 443449 \\
\hline GAPDH & $\begin{array}{l}\text { ATGCCTCCTGCACCACCA } \\
\text { AGTCCCTCCACGATGCCAA }\end{array}$ & 6 & ID: 443005 \\
\hline
\end{tabular}

\section{Statistical analyses}

Myostatin gene expression was estimated through the $2^{-\triangle \mathrm{Ct}}$ method using GAPDH as a reference gene. The gene expression data was analyzed using the Kolmogorov-Smirnov normality test through PROC UNIVARIATE and transformed to square root. Next, the data were 
submitted to ANOVA and the control diet was compared with all treatments with the Dunnett test using PROC GLM. All procedures were performed on SAS (Free Version-University Edition). The level of statistical significance was set at 0.05 .

\section{RESULTS}

All RT PCRs were successful and cycle threshold values were determined. The values ranged from 13.27 to 20.23 for the GAPDH gene and 16.34 to 20.97 for the MSTN gene (Table 2).

Table 2. Ct values for GAPDH and Myostatin genes determined by RT-PCR.

\begin{tabular}{lllll}
\hline \multirow{2}{*}{ Treatments } & GAPDH & & Myostatin & Max \\
\cline { 2 - 5 } & Min & Max & Min & 17.59 \\
Control diet & 14.86 & 17.33 & 16.34 & 18.72 \\
Soybean oil & 13.59 & 16.66 & 17.74 & 20.97 \\
Yellow grease & 13.51 & 20.23 & 17.64 & 19.83 \\
Palm oil & 13.27 & 19.35 & 16.55 & \\
\hline
\end{tabular}

Min= Minimum; Max= Maximum.

The relative MSTN gene expression for each treatment was measured (Figure 1). The control diet consisting of the basic diet plus silage gave the highest relative MSTN gene expression. All treatments with added oil reduced expression; but only the treatment with unused soybean oil gave a significantly lower expression compared to the control diet. Adding of soybean oil down-regulated MSTN expression when compared with used soybean and palm oils.

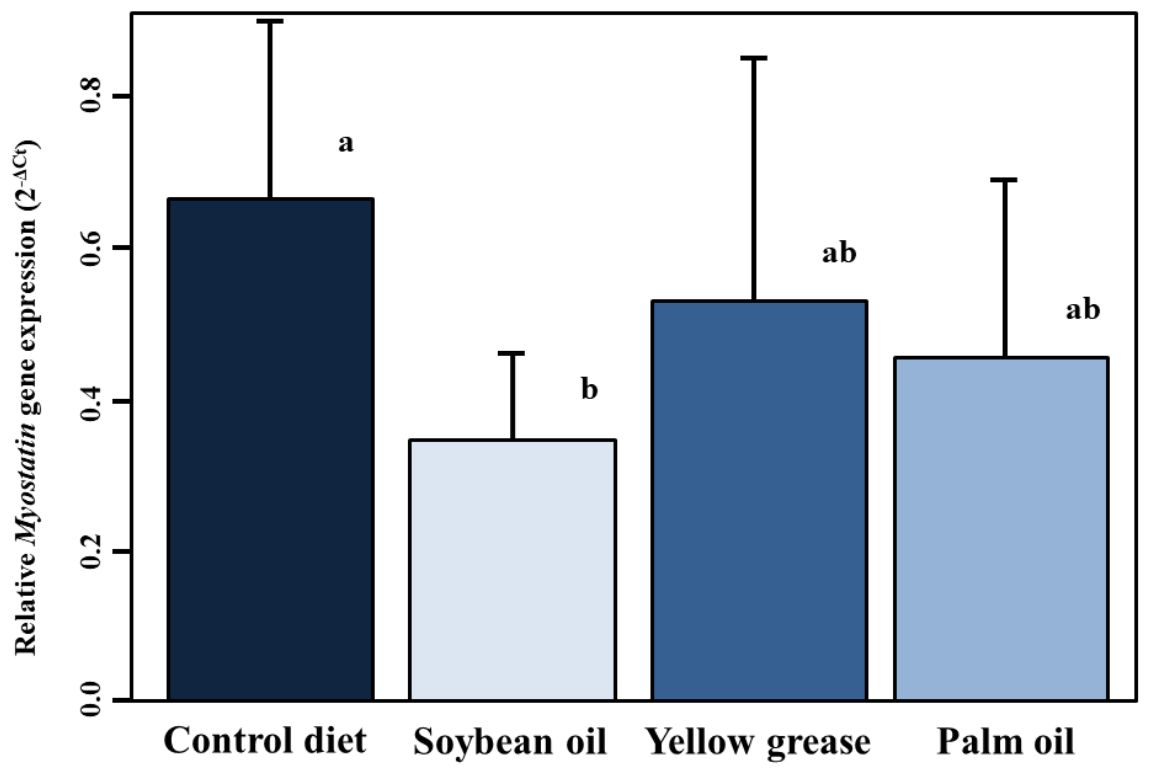

Figure 1. Comparison of Myostatin expression in sheep fed with a standard diet compared with diets to which $4 \%$ soybean oil, used soybean oil (yellow grease) or palm oil was added. Different letters over the bars indicate significant differences $(\mathrm{P}<0.05)$. 


\section{DISCUSSION}

Myostatin expression is regulated by animal nutritional status; when they are under feed restriction or with low energetic level diets, MSTN expression increases (Carneiro et al., 2013). This was found in the control treatment that had the lowest caloric value; however, without the added oil, it had the highest MSTN expression. Zhao et al. (2016) observed that along with muscle development in female lambs, energetic restriction in the diet increases MSTN expression, which may attenuate skeletal muscle development and inhibit the synthesis of certain proteins acting through the Akt-dependent pathway.

In a study of sheep fed a diet without oil MSTN expression significantly decreased in the same muscle in sheep fed with different diets (Xing et al., 2014). On the other hand, Bajatoli et al. (2013) evaluated the effect of MSTN expression on lamb meat quality of several types of sheep, including Santa Inês, 1/2 Santa Inês-Doper and 1/2 White Doper-Santa Inês; they concluded that high MSTN levels are associated with low meat tenderness values.

Diets with low and high fat were tested to determine MSTN expression in the rainbow trout fish (Oncorhynchus mykiss) by Galt et al. (2014). They observed that a highfat diet reduces MSTN expression and alters skeletal muscle lipid content.

Different lipid level diets were tested to determine how they affected the expression of growth related genes in Senegalese sole fish (Solea senegalensis), including MSTN; expression was not affected by the different lipid levels (Campos et al., 2010). Diets containing different kinds of energy altered MSTN expression in geese (Jun-Peng et al., 2008).

Different energetic diet types resulted in different degrees of MSTN expression in sheep muscle (Zhao et al., 2016). Jun-Peng et al. (2008) also found this effect on MSTN expression interacting with $I G F-1$ and $G H$ genes in geese. They observed a significant effect on MSTN expression with different energy source diets.

The addition of oil to the diet decreased MSTN expression, but only with unprocessed soybean oil was it significantly reduced. When the affect of new oil and residual frying oil were compared in a sheep diet, a reduction in intake $(\mathrm{g} / \mathrm{d})$ was observed, principally of dry matter, organic matter, crude protein, neutral detergent fiber, and total carbohydrates, but there was an increased ether extract in the diet containing used frying oil (Peixoto et al., 2017). However, residual soybean oil treatment gave the highest Myostatin expression among all the treatments and may lead to smaller muscle development, i.e. hypoplasia (Reisz-Porszasz et al., 2003). Therefore, sheep fed with diets containing unused soybean oil decrease $M S T N$ gene expression in muscles and may lead to hyperplasia, but it is necessary to associate the MSTN expression with meat quality characteristics, such as carcass yield, tenderness, organoleptic profiles and others.

\section{ACKNOWLEDGEMENTS}

We thank IFPA/Castanhal, CEBTAN, CEBRAN, UFPA for sampling and UFRA for making their laboratories available.

\section{REFERENCES}

Bagatoli A, Gasparino E, Soares MA, Amaral RM, et al. (2013). Expression of calpastatin and myostatin genes associated with lamb meat quality. Genet. Mol. Res. 12: 6168-6175. 
Campos C, Valente LM, Borges P, Bizuayehu T, et al. (2010). Dietary lipid levels have a remarkable impact on the expression of growth-related genes in Senegalese sole (Solea senegalensis Kaup). J. Exp. Biol. 213: 200-209.

Carnac G, Ricaud S, Vernus B and Bonnieu A (2006). Myostatin: biology and clinical relevance. Mini Rev. Med. Chem. 6: 765-770.

Carneiro I, Gonzalez T, Lopez M, Senaris R, et al. (2013). Myostatin expression is regulated by underfeeding and neonatal programming in rats. J. Physiol. Biochem. 69: 15-23.

Du W, Xia J, Zhang Y, Liu MJ, et al. (2015). Expression of recombinant myostatin propeptide pPIC9K-Msp plasmid in Pichia pastoris. Genet. Mol. Res. 14: 18414-18420.

Farhadian M, Hashemi A, Mardani K, Darvishzadeh R, et al. (2012). Polymorphisms in the ovine myostatin gene are associated with birth weight but not with weight gain in Iranian Makoei sheep. Genet. Mol. Res. 11: 3568-3575.

Galt NJ, Froehlich JM, Meyer BM, Barrows FT, et al. (2014). High-fat diet reduces local myostatin-1 paralog expression and alters skeletal musclelipid content in rainbow trout, Oncorhynchus mykiss. Fish Physiol. Biochem. 40: 875886.

Ge G and Greenspan DS (2006). Developmental roles of the BMP1/TLD metalloproteinases. Birth Defects Res. C. Embryo Today. 78: 47-68.

Jun-peng HU, Rui-guo HE, Wei-xing FAN and Ai-qing CAO (2008). Cloning of MSTN Gene and Research of Relationship between MSTN Gene Expression and Different Energy Diets or IGF-I, GH in Serum of Xupu Geese. Acta Vet. et Zootechnica Sinica. 39: 582-587.

Lv XY, Sun W, Su R, Li D, et al. (2015). Correlation between sheep YAP1 temporal and spatial expression trends and MSTN and MyoG gene expression. Genet. Mol. Res. 14: 3244-3256.

Peixoto EL, Mizubuti IY, Azambuja REL, Santos ME, et al. (2017). Residual frying oil in the diets of sheep: intake, digestibility, nitrogen balance and ruminal parameters. Asian-Australas J. Anim. Sci. 30: 51-56.

Reisz-Porszasz S, Bhasin S, Artaza JN, Shen R, et al. (2003). Lower skeletal muscle mass in male transgenic mice with muscle-specific overexpression of Myostatin. Am. J. Physiol. Endocrinol. Metab. 285: E876-888

Tsuchida K (2008). Myostatin inhibition by a follistatin-derived peptide ameliorates the pathophysiology of muscular dystrophy model mice. Acta Myol. 27: 14-18.

Xing HJ, Wang ZY, Zhong BS, Ying SJ, et al. (2014). Effects of different dietary intake on mRNA levels of MSTN, IGF-I, and IGF-II in the skeletal muscle of Dorper and Hu sheep hybrid F1 rams. Genet. Mol. Res. 13: 5258-5268.

Zhao JX, Liu XD, Li K, Liu WZ, et al. (2016). Different dietary energy intake affects skeletal muscle development through an Akt-dependent pathway in Dorper $\times$ Small Thin-Tailed crossbred ewe lambs. Domest. Anim. Endocrinol. 57: 63-70. 